\title{
The US School Superintendent Gender Research Gap Continues: Content Analysis of 2014-2016 Dissertations
}

\author{
Pauline Sampson, Gloria Gresham \\ Stephen F. Austin State University Nacogdoches, Texas, USA
}

\begin{abstract}
Women remain underrepresented in the role of school superintendent in the United States. Current literature revealed women are oppressed when considering gender, characteristics differ from men, and barriers deter women from seeking the role. In this study, a content analysis was conducted of 20142016 US dissertations to ascertain who were the researchers, what were the publication types authors were pursuing to disseminate research, what were the dominate themes in literature reviews of dissertations, of major researchers discovered through the content analysis were these researchers continuing to research women superintendents, and how current was cited research in 2014-2016 dissertations. Findings revealed approximately .002 percent $(43$ of 175,198) of 2014-2016 dissertations dealt with women superintendents. The compilation revealed 1946 references and 1433 authors. Analysis indicated Björk, Brunner, Glass, Grogan, Kowalski, Shakeshaft, Skrla, and Tallerico were cited most often with 636 authors cited only once. The most often used publication type was peer-reviewed articles, with books second, and chapters in books third. Themes revealed leadership, districts, African American, and gender often researched. Topics such as role, barriers, boards, career, experience, social, and power occurred less often and may offer future researchers with gaps to pursue. Major researchers are studying less in the area of women superintendents, doctoral candidates are not using the most current research, and/or current research is not available. Through showcasing issues related to women superintendents, strategies can be implemented to address the low numbers of women superintendents in the field of education.
\end{abstract}

\section{Introduction}

As the United States (US) witnessed a major woman presidential candidate in 2016, the topic of women in leadership roles was more prominent. Some of the issues brought to the forefront during the presidential campaign were family leave, equity in salaries, planned parenthood, and access to healthcare [36]. After the defeat of the
US first major female presidential candidate, many women mourned the missed opportunity of witnessing how a woman would lead the country in a role only previously served by men [12], [21]. Loss of women leaders is prevalent in the field of education's school superintendency. Although the school superintendent role still is filled predominately by men; some women have accessed this position, but women are still drastically underrepresented [1]. Some increase is indicated in women holding the school superintendent position from $13 \%$ in 2000 [2] to $22 \%$ in 2007 [10] and slightly more in 2014 at $24.1 \%$ [25].

This renewed interest in women leaders, especially in the school superintendency, led tothis current research on how US women superintendents are studied in current literature. Doctoral dissertations often are viewed as the most current research since emerging doctoral candidates aim to examine a specific topic and search the most current literature and the gaps to ground their study. Therefore, a content analysis of the most current US dissertations should reveal major issues concerning women superintendents. The examination of current dissertations pertaining to women school superintendents should illuminate the magnitude of research on women superintendents as well as major themes and issues in current research on women superintendents. The purpose of this study was to determine who were the major cited authors on women superintendents in dissertations, the types of publications major authors used for dissemination of their research, the major themes in disserations pertaining to women superintendents, the continued work of the major cited authors, and how current the literature is researched by dissertation candidates. The research questions guiding this study were:

1. Who are the major researchers cited in 2014

- 2016 US dissertations pertaining to women superintendents?

2. What types of documents are authors publishing to disseminate research findings?

3. What are the dominant themes in $2014-2016$ US dissertations pertaining to women superintendents? 4. What is the continued work of the major cited authors on women superintendents? 
5. How current (2009 to 2016) was the cited research in 2014 - 2016 dissertations pertaining to women superintendents?

\section{Literature review}

The theoretical frameworks guiding the present study were based on gender equity issues and feminist theory. Gender inequality relates to unfairness and unequal access for both men and women. Most societies have gender inequities [2] [3], and education has a most obvious gender inequity in leadership. Researchers suggested since some women have made it to the top role in leadership of companies, for example, studies should examine why they were able to obtain the top position. However, many of the studies on gender inequity have only examined a simplistic focus on individual women rather than examining the organization's attributes or potential for women's ascension to top leadership positions.

Feminist theory was another major framework for this study. Feminist theory is way to focus on issues consistently neglected because of male dominated viewpoints in a manner to affect social change [39]. An important construct of feminist theory in the defining of gender roles is dependent on the assumptions that roles of gender are not biological but rather from social learning and expectations [37]. Methodology for feminist research holistically examines issues overlooked or marginalized [9]. The key tenets of feminist theory followed in this current study were (a) a commitment to understanding in order to change gender inequality; (b) a review of gendered practices; and (c) an acknowledgement for epistemological diversity [16].

The researchers of this current study analyzed literature on gender inequity and bias issues, women superintendents and reasons for fewer in the role of superintendent, barriers, and content analysis. Following is a discussion of each topic.

\subsection{Gender inequity or inequality, gender bias, and the school superintendent}

Gender inequity or inequality most often relates to women because they are the population usually marginalized. Women are oppressed when considering gender [30]. Cook and Glass shared that research on women leaders often emphasized the success of some women but rarely looked at the organization or women in general as leaders. Therefore, successful women leaders were viewed as having some exceptional skills rather than other areas contributing to their success. This way of considering individual successful women often leads to marginalizing other women. Additionally, the examination of types of leadership positions taken by women often shows that the positions hold more risk because of context; therefore, women may have lower tenure in the positions and more scrutiny of their work [10], [2].

This higher scrutiny of women's work is often displayed because of gender bias and is experienced by many women superintendents. Researchers determined many women superintendents were very aware of gender bias leading to negative perceptions of their leadership [12], [23]. Gender bias often led to their decisions being challenged and negatively discussed by the community and their school boards.

The hiring of women for the superintendent position has showed discrepancies of practices by school boards and search firms [24]. As women superintendents reflected on the reasons for their hiring, it was usually based on the perception of their expertise in curriculum and instruction. However, men superintendents reflected they were hired because of the personal characteristics. Many school boards and superintendent search firms are composed mostly of men. This leads to unintended bias towards hiring men for the position or at least more knowledge and recognition of other men leaders who may be interested in career advancement to the superintendent position.

\subsection{Women superintendent and reasons for low numbers}

There are conflicting results from studies on reasons why women superintendents have not increased more rapidly. As early as 2000, Glass shared reasons women had not increased in their numbers for the superintendency: their career paths; women choose not to access the superintendent position; limited experience in financial management; family concerns; school boards' hiring practices; and age of women entering administration. Later in 2008, Derrinton and Sharratt suggested in their study of 15 Indiana women superintendents, that women were more qualified, delegated more, and had a stronger work ethic assisting them in achieving the superintendent position.

In 2016, Superville shared there were fewer women superintendents because they did not find the position appealing. Superville also discussed career paths affected women's ability to achieve a superintendent position since women were more often elementary principals, and superintendents were more often hired from secondary principals. However, Robinson, Shakeshaft, Grogan, \& Newcomb shared career paths were not different between men and women as both have different routes to the superintendent position, and women may not have the typical career path.

Networking and mentoring were also reasons for lagging number of women superintendents. Women utilize networks and mentoring differently than men. Women find networks as social support systems 
while men find networks as vehicles for career advancement [42]. Additionally, since there are fewer women superintendents, there are fewer women to serve as role models for upcoming women administrators [17]. Further, some women superintendents are not willing to serve as mentors, and some women administrators are not willing to seek mentors [24] [28]. Other reasons for the lagging numbers of women superintendents are barriers experienced by women attempting to enter the superintendency.

\subsection{Barriers for females entering the superintendency}

Several barriers exist deterring women from the job of superintendent. Derrington and Sharratt found barriers overwhelmingly similar between their 1993 and 2007 study. The barriers included self-imposed barriers of family commitments, immobility, and balancing of work and home. Derrington and Sharratt revealed women who have young children through high school age are the lowest percentage of women holding the job of superintendent. Further these researchers indicated, the role of superintendent has barriers of cultural and social expectations. Gender, characteristics, and barriers faced by women kept many from pursuing the job of superintendent.

Some researchers suggested women question their own ability to do the job of superintendents [13]. Women leaders may question their abilities in finance and facilities management if their background and previous experiences mostly centered around curriculum and instruction. However, Robinson, Shakeshaft, Grogan, \& Newcomb found barriers are not different for men and women. Both men and women leaders have selfimposed barriers of immobility and family commitments.

Another barrier is the hiring process. School board members and search firms often block women because they do not view women as good financial managers and do not desire women as leaders of school districts. Unwritten criteria of school boards may hinder women candidates from obtaining the position [29].

An understanding of reasons for the low numbers of women superintendents is important. Therefore, the examination of who and what is considered important in this research may help understand this phenomenon of lower numbers of women leaders in the educational field. Dissertations provide current research on women superintendents and the issues related to them. Therefore, a content analysis of current US dissertations on women superintendents and current research should provide answers to the issues surrounding women superintendents.

\subsection{Content Analysis}

Content analysis provides a clear manner to find trends and patterns in a major topic such as women superintendents [26]. Content analysis examines: (a) which data are analyzed; (b) how are they defined; (c) what is the population from which they are drawn; (d) what is the context relative to which the data are analyzed; (e) what are the boundaries of the analysis; and (f) what is the target of the inferences [26]. Leavy further described content analysis as a methodical review of texts. It is a method allowing the analysis of important information from a thorough examination of research [26].

Content analysis was used by several researchers to analyze the text of research and dissertations. Content analysis was used by Horton and Hawkins to examine 252 dissertations related to social work doctoral programs. Mete also used content analysis of dissertations related to nursing students and their advisors. Dirliki, Aydin, and Akgün used content analysis methodology to analyze cooperative learning contained in 1993 to 2014 theses. Additionally, Atmac used content analysis to determine the similarities and differences of contextual features.

Other researchers utilizing content analysis included Reynolds studying the inclusion climate of higher education institutions in Oregon, Nicholl researching gender of those in video gaming, Lane analyzing females' fitness research, Marroquin examining gender representation in MexicanAmerican in young adult books, and Angervil looking at the administrative discretion in public policy implementation of No Child Left Behind Act. Many researchers used the method of content analysis to analyze themes and patterns of dissertations and other focused topics.

\section{Methods and Methodologies}

A content analysis was conducted with a detailed search of the last three years (2014-2016) of US dissertations on women superintendents published in the ProQuest database. The ProQuest dissertations and theses is a major repository of dissertations used in the US. A detailed search was conducted on the ProQuest database for 2014 - 2016 dissertations with the key words female superintendents and women superintendents. Abstracts were reviewed if it was unclear if the dissertation pertained to women superintendents.

Reference lists from all dissertations on women superintendents were copied into a Word document. Each reference list was analyzed and references were removed not relating to the terms female or women superintendents. Reference citations including these terms were transferred and categorized on a table (Citation Table): superintendents, female, women, 
administrators, educational leadership, leadership, gender, and feminist. The Citation Table included these labels: (1) dissertation title; (2) Proquest number;

(3) citation including author name; (4) publication type [peer-reviewed article, chapter, book, other (papers, presentations, blogs, etc.).

The Citation Table was sorted by citations to determine the authors displayed. Next, the authors were counted to locate how many times each author's name was revealed in the dissertations. For citations with multiple authors, each author's name frequency was counted.

An additional table (Author Count) was created with these categories: (1) author (frequency the author's name appeared in the references lists); (2) count (the number of authors displaying the frequency). The table was then sorted to determine the frequency for the authors. To locate the publication type, the Citation Table was sorted by publication type.

The next section of this content analysis was the examination of the headings in the literature review section of all chosen dissertations on women superintendents. The headings were typed into an Excel spreadsheet. This Excel sheet was imported to NVivo11, a software program to run a frequency "Word Query," to determine the major words used. Next, the literature review from all chosen dissertations was also uploaded to NVivo 11 to ascertain themes. The use of NVivo 11 eased the management of a large volume of text-based data.

Finally, the most frequently cited authors found were then researched through the databases of Google Scholar, Academic Search Complete, WorldCat, and Education Resources Information Center (ERIC) to determine if they were still researching women superintendents. Then, the citations of the 43 dissertations were analyzed to determine if literature utilized in the dissertations was current, as occurring in the span of 2009-2016 since some dissertations were published in 2014 and some up to 2014. The researchers defined current literature as no more than five years old.

\section{Analysis of Findings}

The three years (2014-2016) of published dissertations written in the US and published in Proquest showed 175,198 dissertations. Approximately 43(.002\%) of dissertations related to women superintendents. The following research questions were answered from a content analysis of the 43 dissertations, and the next section is organized by the research questions.

\subsection{Who are the major researchers cited in 2014 - 2016 US dissertations pertaining to women superintendents?}

There were 1,946 cited references and 1,433 cited authors in the 43 dissertations on women superintendents. The frequency of authors cited ranged from one to 243. Most authors had one citation (636). The authors with the highest number of citations showed a frequency of 40 or more citations. This analysis determined who was impacting the scholarly work on women superintendents' research. Table 1 outlines the frequency that an author's name was displayed on the references lists and the number of authors with the same frequency count. For example, Table 1 reveals that 636 authors were cited one time on the combined references lists. See Table 1.

\begin{tabular}{cc} 
Table 1. Author Count \\
Frequency referenced & Number of authors \\
\hline 1 & 636 \\
2 & 157 \\
3 & 76 \\
4 & 43 \\
5 & 28 \\
6 & 12 \\
10 & 7 \\
11 & 3 \\
12 & 2 \\
13 & 5 \\
14 & 4 \\
15 & 2 \\
16 & 4 \\
17 & 3 \\
18 & 1 \\
20 & 1 \\
21 & 2 \\
22 & 3 \\
23 & 1 \\
24 & 1 \\
26 & 1 \\
27 & 2 \\
29 & 2 \\
30 & 1 \\
49 & 1 \\
50 & 1 \\
57 & 1 \\
62 & 2 \\
65 & 1 \\
148 & 1 \\
243 &
\end{tabular}

Authors who exhibited frequencies of 40 or more citations were Björk, L. G. (44); Brunner, C. C. (243); Glass, T. E. (59); Grogan, M. (160);

Kowalski, T. (60); Shakeshaft, C. (55); Skrla, L. (46); and Tallerico, M. (57). The latest publication dates of these frequently cited authors in the 43 dissertation references lists cited ranged from 2004 to 2012. See Table 2. 
Table 2. Latest Publication Year of Frequently Cited Authors

\begin{tabular}{ccc} 
Author & \multicolumn{2}{c}{ Year } \\
\hline Bjork & 2008 \\
Brunner & 2012 \\
Glass & 2007 \\
Grogan & 2011 \\
Kowalski & 2012 \\
Shakeshaft & 2011 \\
Skrla & 2008 \\
Tallerico & 2004
\end{tabular}

\subsection{What types of documents are authors publishing to disseminate research findings?}

The publication type was defined as peerreviewed articles, books, chapters, and others such as blogs or newspaper articles. The type was determined by sorting the citations of the 43 dissertations by the publication types and making a count for each publication type. Table 3 outlines the number of publications for the categories of peerreviewed articles, books, chapters in books, and other (newspaper articles, magazine articles, papers, presentations, blogs, etc.). The majority of the publications (965) were peer-reviewed articles.

\begin{tabular}{rrrr}
\multicolumn{5}{c}{ Table 3. Publication Type } \\
Articles & Books & Chapters & Other \\
\hline 965 & 542 & 180 & 108
\end{tabular}

\subsection{What are the dominant themes in 2014 - 2016 US dissertations pertaining to women superintendents?}

The literature review for the 43 selected dissertations was analyzed by examining headings, subheadings, and frequency of words in the reviews. The headings and subheadings from all chapters were copied to a Word document. The document then was imported into the NVivo 11 software program. A "Word Query" from NVivo was then conducted to determine the frequency of words in the headings and subheadings to ascertain the major themes. Table 4 displays the frequency of the words in headings and subheadings. The range of occurrences reported were seven to 185 .

Further, the literature review from the 43 selected dissertations provided a document of 790 pages. The analysis focused on the most frequent words used in the literature reviews to find the major content of the literature reviews. The word document from the combined dissertations was imported to NVivo 11 software program. A "Word Query" was conducted in NVivo with the results displayed in Table 5. The most frequent words (above 1900 occurrences) in the combined Review of Literatures from the 43 dissertations were women/female, superintendents, leadership, school districts, and men/male

\begin{tabular}{|c|c|}
\hline Women/Female & 185 \\
\hline Superintendents & 131 \\
\hline Leadership & 91 \\
\hline Theory & 60 \\
\hline History/ historical & 41 \\
\hline Barriers & 38 \\
\hline African American/black & 36 \\
\hline Role & 34 \\
\hline Gender & 27 \\
\hline School & 21 \\
\hline Feminist & 20 \\
\hline Education & 19 \\
\hline Social & 17 \\
\hline Research & 11 \\
\hline Development & 9 \\
\hline Cultural & 9 \\
\hline Public & 9 \\
\hline State & 8 \\
\hline Context & 8 \\
\hline Critical & 8 \\
\hline Demographics & 8 \\
\hline Framework & 7 \\
\hline Approach & 7 \\
\hline Board & 7 \\
\hline Instructional & 7 \\
\hline Mentoring & 7 \\
\hline Networks & 7 \\
\hline Position & 7 \\
\hline Power & 7 \\
\hline Professional & 7 \\
\hline Review & 7 \\
\hline Studies & 7 \\
\hline Support & 7 \\
\hline
\end{tabular}

Table 5. Chapter Two Review of Literature Word Count

\begin{tabular}{lc} 
Word & Number \\
\hline Women/female & 9,094 \\
Superintendents & 6,943 \\
Leadership & 3,385 \\
Schooldistricts & 2,967 \\
Men/male & 2,071 \\
African American & 1,978 \\
Study & 1,281 \\
Gender & 1,280 \\
Education & 047 \\
Positions & 1,045 \\
Role & 908 \\
Research & 836 \\
Barriers & 726 \\
Career & 694 \\
Social & 639 \\
Work & 603 \\
Board & $5 / 3$ \\
Districts & 572 \\
Experience & 553 \\
Power & 530 \\
Theory & 517
\end{tabular}




\subsection{What is the continued work of the major cited authors on women superintendents?}

The search of major cited authors was conducted to determine if they continue work on women superintendents. This search found that Bjork, Brunner, Glass, Skrla, and Tallerico have no further publications on women superintendents in the 20092016 span. However, Grogan, Kowalksi, and Shakeshaft have continued their work on women superintendents. Grogan has four publications on women superintendents in the 2009-2016 span. Kowalski has one additional publication on women superintendents in the 2009-2016 span. Shakeshaft has five additional publications on women superintendents in the 2009-2016 span.

\subsection{How current (2009 to 2016) was the cited research in 2014 - 2016 dissertations pertaining to women superintendents?}

An examination of the review of literature from the 43 dissertations was analyzed by examining the percentage of citations matching the 2009-2016 span from the overall references in review of literature chapters that pertained to the search terms superintendents, female, women, administrators, educational leadership, leadership, gender, and feminist. Table 6 shows the number of dissertations that had ranges percentages matching the span of 2009-2016 and considered current literature by researchers.

Table 6: Percentages of References in Span of 2009. 2016

\begin{tabular}{cc}
$\begin{array}{l}\text { Percentage of Span } \\
2009-2016 \\
\text { Dissertations }\end{array}$ & $\begin{array}{l}\text { Number } \\
\text { of }\end{array}$ \\
\hline $0-10$ & 7 \\
$11-20$ & 15 \\
$21-30$ & 12 \\
$31-40$ & 4 \\
$41-50$ & 5
\end{tabular}

Most of the citations related to women superintendents were not current. There were nine dissertations with 41-50 percent of their total citations between the years 2009-2016. Four dissertations had 31-40 percent of their citations within the last five years. Twelve of the dissertations had 21-30 percent of their citations within the last five years. Fifteen of the dissertations had 11-20 percent of their citations between the years 20092016. Seven of the dissertations had 0-10 percent of their citations with the last five years.

\section{Discussion}

The purpose of this study was to understand current research on women superintendents by conducting a content analysis of three years of US dissertations. The content analysis was used to determine who were the cited authors, what were the chosen types of publications, what were the major themes displayed in 2014-2016, what major authors continued research, and what percentage of citations in dissertations were current in US dissertations referring to women superintendents. Only a small portion (.002 percent) of all US dissertations were related to women superintendent between the years 2014-2016.

Data for research question 1 (Who are the major researchers cited in 2014-2016 US dissertations pertaining to women superintendents?) showed 1946 cited references and 1433 cited authors. There were 636 authors cited only one time while eight authors were cited more than 40 times. Major researchers cited in the dissertations were Björk, L. G.; Brunner, C. C.; Glass, T. E.; Grogan, M.; Kowalski, T.; Shakeshaft, C.; Skrla, L.; and Tallerico, M. Further. Findings indicated dissertation candidates may not seek the most current research, did not update literature reviews prior to publication, or little current research was available in the area of women superintendents.

Findings for question 2 (What types of documents are authors publishing to disseminate research findings?) revealed the type most often referenced in the dissertations was peer-reviewed articles (965). The next most frequent publication types cited in the dissertations were books and chapters. Peer-reviewed journal articles are the traditional expectation for literature reviews of dissertations, and this research supported this tradition.

Evidence for research question 3 (What are the dominant themes in 2014-2016 US dissertations pertaining to women superintendents?) showed the most common themes (cited over 2000 times) in dissertation literature reviews were female/women, men/male, and superintendents. The next most frequent themes were leadership, school districts, African American, gender, education, and position displayed in a range of 1045 to 1978 times. Themes of role, barriers, career, social, board, experience, and power occurred in the range of 530 to 908 times. Findings revealed gaps or areas to pursue.

Question 4 (What is the continued work of the major cited authors on women superintendents?) details indicated five major authors identified (Björk, Brunner, Glass, Skrla, Tallerico) are no longer publishing in the area of women superintendents. While Grogan (four), Kowalski (one) and Shakeshaft (five) are continuing to research in this area. Findings showed a possible decrease in women superintendent research. 
Finally, for question 5 [How current (2009 to 2016) was the cited research in 2014-2016 dissertations?] evidence revealed most of the citations dissertation candidates utilized relating to women superintendents were not current. Dissertation candidates are not using current research, or current research in the area of women superintendents is not available.

\section{Conclusion}

Women remain underrepresented as superintendent in the US [2], [10], [1]. The analysis of 2014 - 2016 current US dissertation research indicated the study of women superintendents remained a low priority with only about .002 percent (43 of 175,198) of US dissertations dedicated to this topic. Educational leadership doctorate preparation programs are encouraged to enhance critical need area research through facilitating the development of candidate skills in methodically analyzing current research to determine what important gaps exist such as women in the superintendency and how to highlight those areas through research and publications. Additionally, there is very little research on the political nature of the superintendent position and how that might affect women superintendents or women desiring to enter the leadership field. Further, minimal research is conducted on the organization of schools to determine the context that might support women in leadership roles.

Several themes were prominent in the 43 dissertations on women superintendents. Most of the themes were women/female and superintendents, leadership, gender, school districts, African Americans, and position. Other themes were role, barriers, career, social, board, experience, and power. The themes of career, school board, experience and power may be areas for future research. These areas may provide gaps to be researched as they relate to women superintendents.

The major researchers according to the content analysis of dissertations were Björk, Brunner, Glass, Grogan, Kowalski, Shakeshaft, Skrla, and Tallerico from the years 2004 to 2012. These authors were cited most frequently in the literature reviews of dissertations on women superintendents. However, not all of these cited researchers have maintained a current agenda of research on women superintendents. Only Grogan, Kowalksi, and Shakeshaft have continued to publish research on women superintendents. Current women superintendent research is critical to highlight the low numbers still prevalent.

It was interesting to note that many doctoral candidates writing dissertations did not use current research as defined within the last five years. Only nine of the 43 dissertations had approximately 50 percent of their cited references within the last five years. There were 34 of the 43 dissertations exhibiting less than 30 percent of their cited references in the last five years. The low percentage usage of current cited references is concerning since dissertations are usually expected to showcase the most recent research related to a topic, and this was not evident in this research study.

The researchers of this study urge others to increase research and publications on women superintendents. Highlighting women superintendent issues has the possibility of influencing more women to enter the superintendent position. Additional study on the issues of women superintendents could help define the reasons for low numbers of women superintendents in US. Additionally, more research on women superintendents and the school context as an organization may draw public attention to the discrimination of women in leadership roles.

\section{References}

[1] Derrington, A.B., Sharratt, G., "Female Superintendents: Breaking Barriers and Challenging Life Styles", Delta Kappa Gamma Bulletin, Delta Kappa Gamma, Austin, Texas, 2009, pp. 8-12.

[2] Cook, A., and Glass, C., "Women and Top Leadership Positions: Toward an Institutional Analysis", Gender, Work \& Organization, Wiley Online Library, 2014, pp. 91 103.

[3] Curthoys, A., "Gender Studies in Australia: A History", Australian Feminist Studies, Australia, 2015, pp. 19-38.

[4] Lane, A., "Can She Work Out, Too? A Content Analysis of Muscle and Fitness". ProQuest Dissertations and Full Theses, 2017.

[5] Muñoz, A.J., Pankake, A., Ramalho, E. M., Mills, S., and Simmonsson, M., "A Study of Women Central Office Administrators and Their Aspirations to the Superintendency", Educational Management Administration and Leadership, 2014, pp. 764-784.

[6] Peters, A., "Elements of Successful Mentoring of a Women School Leader", Leadership and Policy in Schools, 2010, pp. 108-129.

[7] Allen, J., and Parnes, A., (2017). The Moment Hillary Clinton was Forced to Give Up Her Dream. New York Post, 2017. http://nypost.com/2017/04/30/the-momentHillary-Clinton-was-forced-to-give-up-her-dream. (Access Date: 29 August, 2017).

[8] Atmaca, C., "Comparison of Hedges in M. A. Theses and Ph.D. dissertations in ELT", ZfWT, 2016, pp. 309325.

[9] Brooks, A. and Hesse-Biber, S.N., "An Invitation to Feminist Research", In S. N. Hesse Biber and P. L. Leavy (Eds.), Feminist Research Practice, Sage Publications, Thousand Oaks, California, 2007. 
[10] Bruckmuller, S. M. Ryan, Rink, L, and Haslam, S. "The Glass Cliff: Examining Why Women Cccupy Leadership Positions in Precarious Situations. In S. Kumra, R. Simpson, and R. Bruke (Eds.), Oxford handbook of gender in organizations, Oxford University Press: NY, 2017.

[11] Brunner, C.C., and Grogan, M., (2007). Women Leading School Systems: Uncommon Roads to Fulfillment. Rowman and Littlefield Education, Lanham, Maryland, 2007.

[12] Kelsey, C., Allen, K. Coke, K. and Ballard, G., "Lean In and Lift Up: Female Superintendents Share their Career Path Choices", Journal of Case Studies in Education, AABRI, 2014, pp. 10-11.

[13] Dobie, D.F., and Hummel, B., "Successful Women Superintendents in a Gender-biased Profession", Equity and Excellence in Education, pp. 22-28, DOI: 10.1080/1066568010340204, 2006)

[14] D. S. Reynolds, D.S., "A Content Analysis: Inclusion Climate in Higher Education in the Oregon University System of Seven Oregon Universities", ProQuest Dissertations and Full Theses, 2017.

[15] Dirliki K. Aydin, D.K., and Akgün, L., "Cooperative Learning in Turkey: A Content Analysis of Theses", Educational Sciences: Theory and Practice, 2016, DOI: 1012738/estp.2016.4.0142, pp. 1252-1273.

[16] Nelli, D.K., "Gender Representation in U. S. Ed.D Dissertations: A Feminist Content Analysis", ProQuest Dissertations and Full Theses, 2014.

[17] D. R. Superville, "Few Women Run School Districts Why?", Education Week, 2016, pp. 9-10.

[18] Horton, E.G. and Hawkins, M., "A Content Analysis of Intervention Research in Social Work Doctoral Dissertations", Journal of Evidence-Based Social Work, Routledge Taylor and Francis Group, 2010, DOI: 10.1080/15433710903344066, pp. 377 386.

[19] Nicholl, G.A., "A Content Analysis of Gender Representations in Independent Video Games", (Doctoral dissertation). ProQuest Dissertations and Full Theses, 2017, DOI: $10.1177 / 1745691615592234$.

[20] Angervil, G., "Administrative Discretion in Public Policy Implementation: The Case of No Child Left Behind (NCLB). ProQuest Dissertations and Full Theses, 2017.

[21] Haelle, T., Still Grieving Trump's Win? You're Not Alone. Forbes, 2016. https://www.forbes.com/stites/taraha elle/2016/11/30/still-grieving-trumps-win-you're-notalone. (Access Date: 29 August, 2017).

[22] Acker, J., "Inequality Regimes: Gender, Class, and Race in Organizations", Gender and Society, Sociologists for Women in Society, Lawrence, Kansas, 2006, pp. 441464.
[23] Whitaker, J.E., "Women in the Middle: A Qualitative Study of the Leadership Experiences of Women Central Office Administrators", (Doctoral dissertation). ProQuest dissertation database (\# 3226986), 2006.

[24] Robinson, K., Shakeshaft, C., M. Grogan, and Newcomb, W. S., "Necessary But Not Sufficient: The Continuing Inequality between Men and Women in Educational Leadership Findings from the AASA MidDecade Survey", Frontiers in Education, Chapman University, 2017, pp. 1-12.

[25] Kowalski, T. J., McCord, R. S., Petersen, G. I., Young, P. I., and Ellerson, N. M. (2011). The American School Superintendent 2010 Decennial Study. Rowan and Littlefield Education, Lanham, Maryland, 2014.

[26] Knippendorff, K., Content Analysis: An Introduction to its Methodology (2nd Ed). Sage Publications, Newbury Park, California, 2004.

[27] Leavy, P. L., "The Feminist Practice of Content Analysis. In S. N. Hesse-Biber and P. L. Leavy (Eds.), Feminist Research Practice: A Primer. Sage Publications, Thousand Oaks, California, 2007.

[28] L.Searby, and Tripses, J. (2006). "Breaking Perceptions of "Old Boys Networks": Women Leaders Learning to Make the Most of Mentoring Relationships.", Journal of Women in Educational Leadership, 2006, pp. 179-195.

[29] Skrla, L., Reyes, P., and Scheurich, J. J., (2000). "Sexism, Silence, and Solutions: Women Superintendents Speak Up and Speak Out", Educational Administration Quarterly, 2000, pp. 4475.

[30] McLean, L.L., La Guardia, A.C., J. A. Nelson, and Watts, R. E., "Incorporating Adlerian and Feminist Theory to Address Self-objectification in Couple's Ttherapy, Sage Publications, Newbury Park, California, 2016.

[31] M. D. Young. "Shifting Away from Women's Issues in Educational Leadership in the US: Evidence of a backlash?", International Studies in Educational Administration, 2005, pp. 31-42

[32] Marroquin, M., "Gender Representation in MexicanAmerican Young Adult Books. A Content Analysis". ProQuest Dissertations and Full Theses, 2017.

[33] Tallerico, M., "Gaining Access to the Superintendency: Headhunting, Gender, and Color", Educational Administration Quarterly, University Council for Educational Administration, 2000, pp. 18- 43

[34] Bañuelos, M.V., "Breaking the Silence: Gender Bias in the Top Ranks", Leadership, Association of California School Administrators, 2008, pp. 28-30.

[35] O'Rouke, M., Mourning Trump and the America We Could Have Been. The New Yorker, 2016. http://www.newyorker.com/culture/culturedesk/mourningtrump-and-the-america-we-could-have-been. (Access Date: 29 August, 2017). 
[36] Mosendz, P., "5 Important Issues that Matter to Women in the 2016 Presidential Election," TeenVogue, [Internet], USA, March 2016, para. 15. http://www.teenvogue.com/story/important-womensissues-2016-election. (Access Date: 30 November, 2016).

[37] Thomas, S. A., "Theory and Practice in Feminist Therapy”, Social Work, 1997, pp. 447-454.

[38] Mete, S., "Using a Nursing Theory or a Model in Nursing PhD Dissertations: A Qualitative Study from Turkey", International Journal of Nursing Knowledge, NANDA International, Inc., 2014, pp. 62-72.

[39] Stanley, L., Feminist praxis (RLE feminist theory): Research theory and epistemology in feminist sociology. Routledge, New York, 2013.

[40] T. E. Glass, "Where Are All the Women Superintendents?", American Association of School Superintendents, [Internet], Alexandria, Virginia, 2000, para. 39. http://www.aasa.org/SchoolAdministrator

Article.aspx?id=14492. (Access Date: 25 November, 2016).

[41] Glass, T.E., and Franceschini, L.A., The State of the American Superintendency. American Association of School Administrators, Alexandria, Virginia, 2007.

[42] Singh, V., Vinnicombe, S., and Kumra, S., "Women in Formal Corporate Networks: An Organizational Citizenship Perspective", Women in Management Review, 2006, pp. 458-482. 